\title{
Validity of Histopathologic Lesions in the Diagnosis of Fibrotic Interstitial Lung Diseases
}

\section{Fibrotik İnterstisyel Pnömoni Tanısında Histopatolojik Lezyonların Değeri}

\author{
๑ Halide Nur Ürer ${ }^{1}$, Neslihan Fener $^{1}$, ๑ Nurcan Ünver ${ }^{1}$, ๑ Erdoğan Çetinkaya² \\ ${ }^{1}$ University of Health Sciences Turkey, Yedikule Chest Disease and Thoracic Surgery Training and Research Hospital, Clinic of Pathology, Istanbul, Turkey \\ ${ }^{2}$ University of Health Sciences Turkey, Yedikule Chest Diseases and Thoracic Surgery Training and Research Hospital, Clinic of Pulmonary Medicine, Istanbul, Turkey
}

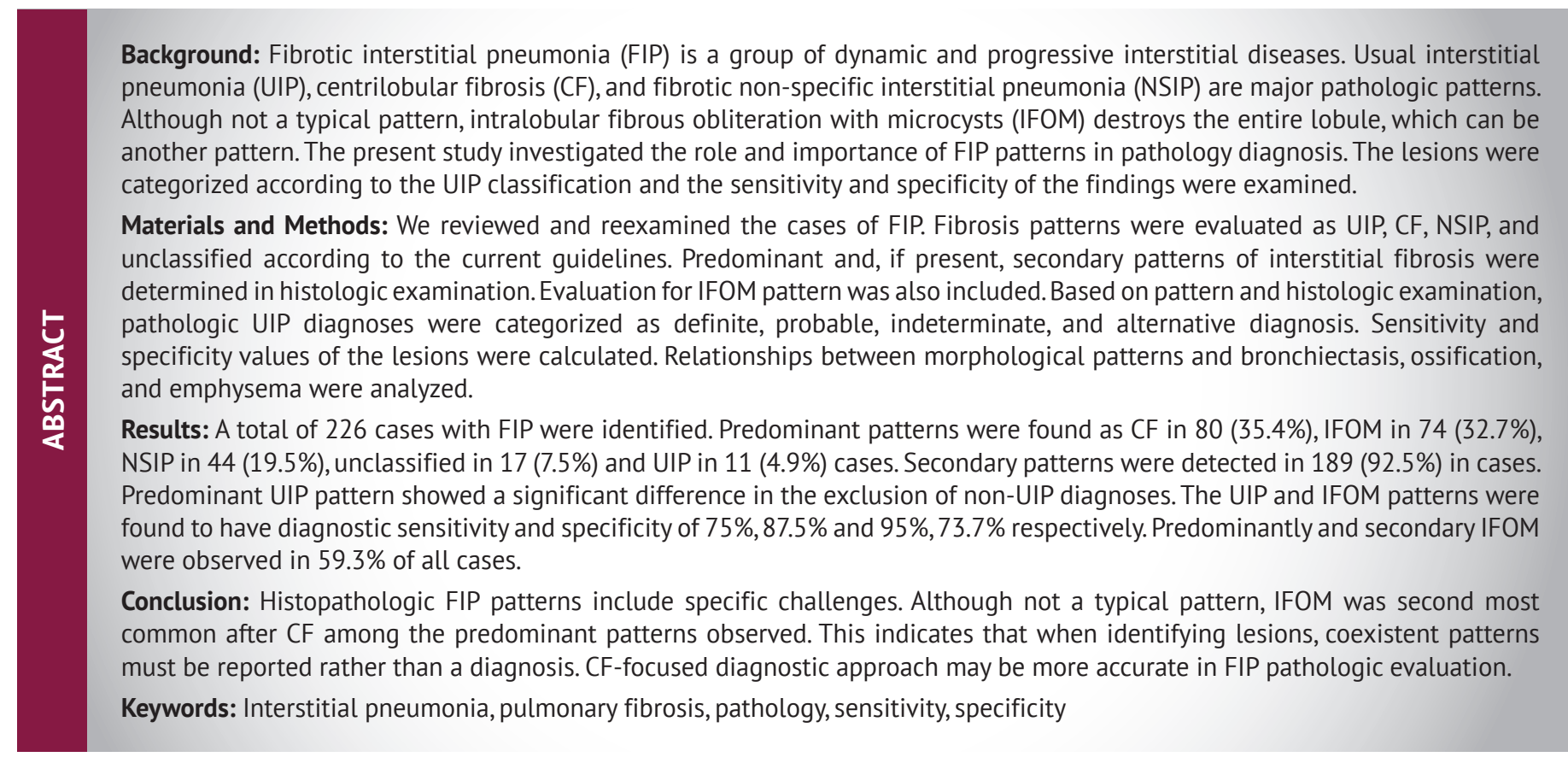

\footnotetext{
Amaç: Fibrotik interstisyel pnömoni (FiP) akciğer interstisyumun ilerleyici ve dinamik bir hastalık grubudur. Usual interstisyel
pnömoni (UIP), sentrilobüler fibrozis (SF), fibrotik non-spesifik interstisyel pnömoni (NSiP) majör paternlerdir. Tipik bir patern
olmasa da kistik intralobüler obliteratif fibrozis (KiOF) lobülü tümüyle ortadan kaldıran bir diğer patern olabilir. Çalışmanın
amacı FiP patoloji tanısında paternlerin önemini araştırmaktır. Lezyonları UiP sınıflamasına göre değerlendirerek sensitivite ve
spesifiteyi belirlemektir.
Gereç ve Yöntemler: FiP tanılı olgular tekrar değerlendirilerek incelendi. Fibrozis paterni güncel rehberlere göre UiP, SF, NSiP ve
sınıflanmayan olarak gruplandı. Baskın patern ve eğer varsa sekonder patern arandı. Ayrıca KiOF patern olarak değerlendirildi. UiP
kesin, olası, belirsiz ve alternatif tanı olarak gruplandı. Lezyonların sensitivite ve spesifite değerleri hesaplandı. Morfolojik patern
ile bronşektazi, ossifikasyon, amfizem arasında ilişki araştırıldı.
Bulgular: Toplam 226 FiP olgusu saptandı. Baskın patern SF 80 (\%35,4), IFOM 74 (\%32,7), NSiP 44 (\%19,5), sınıflanmayan 17 (\%7,5)
ve UiP 11 (\%4,9) olguda bulundu. Sekonder patern 189 (\%92,5) olguda izlendi. Baskın UIP patern UiP dışı tanıyı dışlamada anlamlı
}

Address for Correspondence: Halide Nur Ürer, University of Health Sciences Turkey, Yedikule Chest Disease and Thoracic Surgery Training and Research Hospital, Clinic of Pathology, İstanbul, Turkey

Phone: +90 5052659365 E-mail: nururer@gmail.com ORCID ID: orcid.org/0000-0002-0549-9969

Received: 17.10.2020 Accepted: 17.11.2020 
fark gösterdi. UiP paternin tanısal sensitivite ve spesifitesi \%75 ve \%95 idi. Baskın ve sekonder IFOM paterni \%59,3 bulundu. IFOM'un UiP tanısında sensitivite ve spesifite değeri \%87,5 ve \%73,7 idi.

Sonuç: Histopatolojik FIP paternlerin kendine özgü güçlükleri bulunur. IFOM tipik patern olmasa da SF'den sonra en sık saptanan paterndir. Bu durum tanıdan ziyade lezyonların tanımlanması gerekliliğini göstermektedir. SF odaklı tanısal yaklaşım FiP’nin patolojik değerlendirmesinde daha öncelikli olabilir.

Anahtar Kelimeler: Interstisyel pnömoni, pulmoner fibrozis, patoloji, sensitivite, spesifite

\section{Introduction}

Fibrotic interstitial pneumonia (FIP) is a group of interstitial lung diseases with varying clinical, radiological, and pathological findings, each characterized by a unique pathological pattern.

The key point in the diagnosis and treatment of an interstitial disease is whether it is idiopathic pulmonary fibrosis (IPF). Current classifications recommend that the diagnosis of FIP should be based on a multidisciplinary clinicoradiologic/pathologic consensus $(1,2)$. Marked clinical and radiologic findings are sufficient for diagnosis. If these findings are insufficient, biopsy is recommended (3). The presence and distribution of lesions in pathologic evaluation determine the specific histological pattern. Major fibrotic patterns are usual interstitial pneumonia (UIP), centrilobular fibrosis (CF), and fibrotic non-specific interstitial pneumonia (NSIP) (4). UIP is the pathologic diagnosis of IPF and $\mathrm{CF}$ is the prototype of the hypersensitivity pneumonia. Fibrosis lacking a characteristic pattern is defined as unclassified.

In cases with ambiguous clinicoradiologic findings, pathologic examination of biopsy specimens is important. The presence of unexpected lesions together with typical patterns can make diagnosis challenging.Although not a typical pattern, intralobular fibrous obliteration with microcysts (IFOM) destroys nearly the entire lobule and is an important lesion of progressive fibrosis (5). Because typical patterns are obliterated with the formation of diffuse fibrosis, the interstitium resembles a fireplace where histologic clues are lost. The histologic presentation may be equivalent to that of end-stage disease. A specific diagnosis is only possible if there is a typical pattern accompanying destructive fibrosis.

The present study investigated the role and importance of fibrotic interstitial lung disease patterns in pathology diagnosis. The lesions were categorized according to the UIP classification and the sensitivity and specificity of the findings were analyzed.

\section{Material and Methods}

Cases with a provisional diagnosis of interstitial lung disease, who underwent open or video-assisted wedge resection of the lung, were included in the study. Pathology reports from 2013 to 2019 were reviewed and cases diagnosed with interstitial fibrosis were selected. The cases' slides were reevaluated under light microscopy by the researchers (H.N.U., N.U., N.F.). Predominant and, if present, secondary patterns of interstitial fibrosis were determined in histologic examination. Fibrosis patterns were evaluated as UIP, CF, NSIP, and unclassified according to the current guidelines (Figure 1a,b,c,d) (1,2). Evaluation for IFOM pattern (obliteration of the lobular structure) was also included (Figure 2). Fibroblastic focus (FF) findings were graded as none, sporadic (fewer than 3 in field of view at low magnification), and diffuse (3 or more). Honeycomb fibrocysts, bronchiectasis, interstitial ossification, and emphysema were sought. In addition, minor changes such as well-formed and loose granuloma, centrilobular interstitial isolated giant cells, desquamative pneumonia, organizing pneumonia, smokingrelated interstitial fibrosis (SRIF), pleuritis and inorganic dust accumulation, intense inflammation, and increase in lymphoid follicles were investigated. And also, pleuroparenchymal fibroelastosis was evaluated. Based on pattern and histologic examination, pathologic UIP diagnoses were categorized as definite, probable, indeterminate, and alternative diagnosis according to the current guidelines.

Interstitial diseases characterized by cysts were excluded even if FIP was present. Those were Langerhans cell histiocytosis, lymphangioleiomyomatosis, and Birt-Hogg-Dubé (BHD) syndrome. Cases with carcinoma were not included in the study.

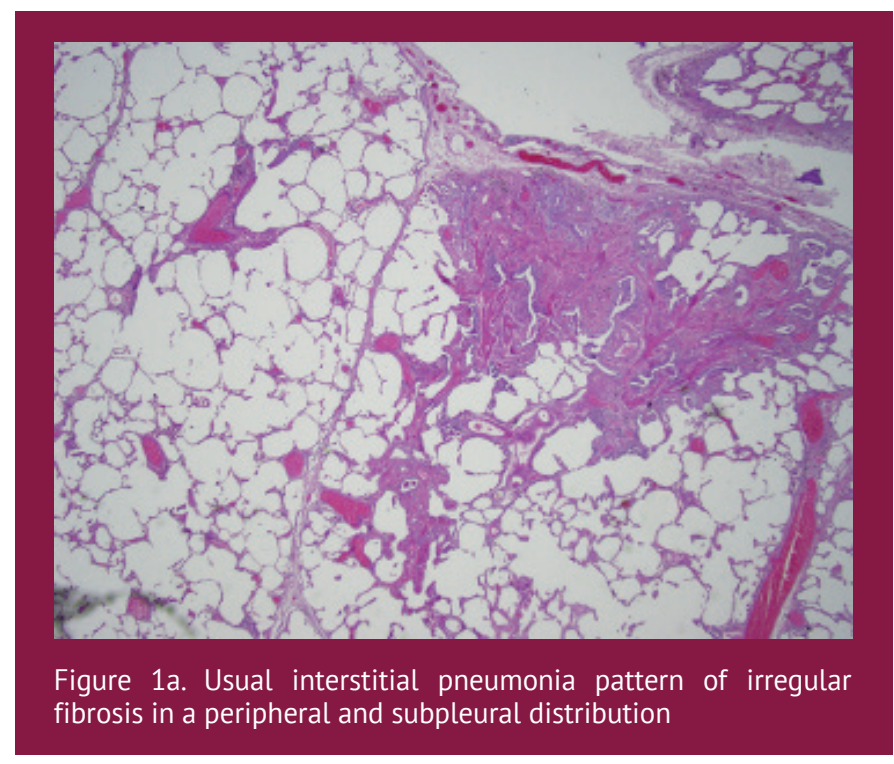




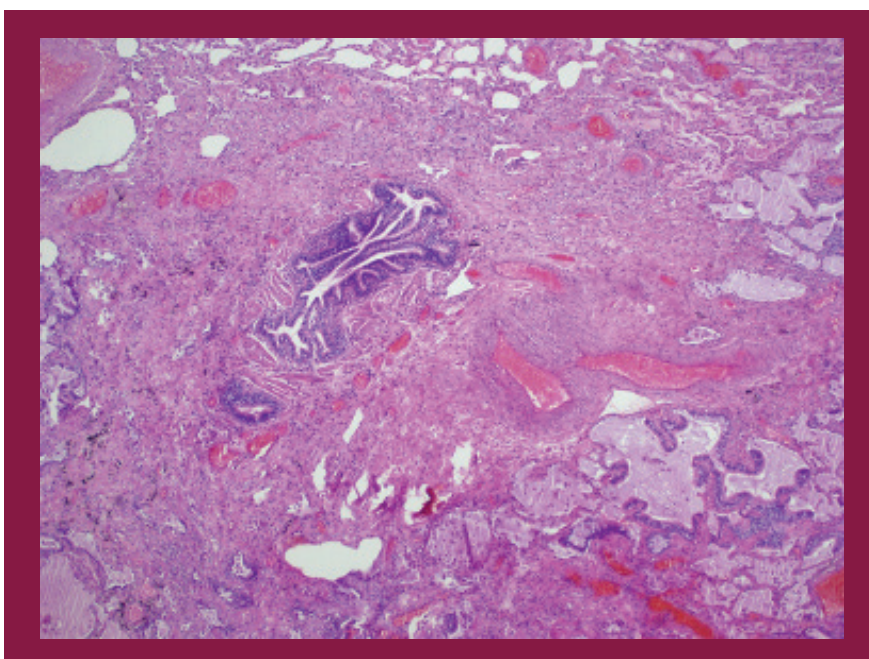

Figure 1b. Centrilobular pattern of fibrosis with airway-centered centrilobular fibrosis

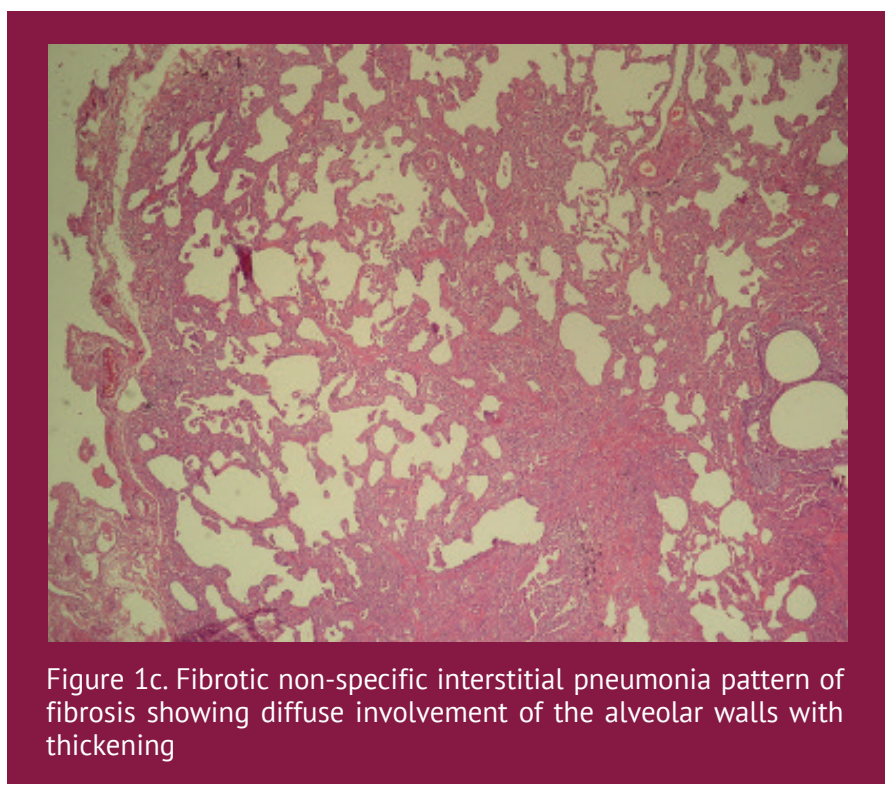

Study design was approved by Local Ethical Committee (University of Health Sciences Turkey, İstanbul Training and Research Hospital). The study protocol number and date are $2259 / 20(08 / 05 / 2020)$. And also, it was approved by Hospital Science Committee (protocol number is 244-5/20), and informed consents were obtained from all study patients.

\section{Statistical Analysis}

The data were evaluated using statistical methods. Sensitivity and specificity values were calculated for histologic lesions and diagnoses. Patterns defined as possible UIP and alternative diagnosis were grouped as non-UIP, while the others were grouped as UIP. Relationships between morphological patterns and bronchiectasis, ossification, and emphysema were analyzed. For categorical variables, frequencies were compared using

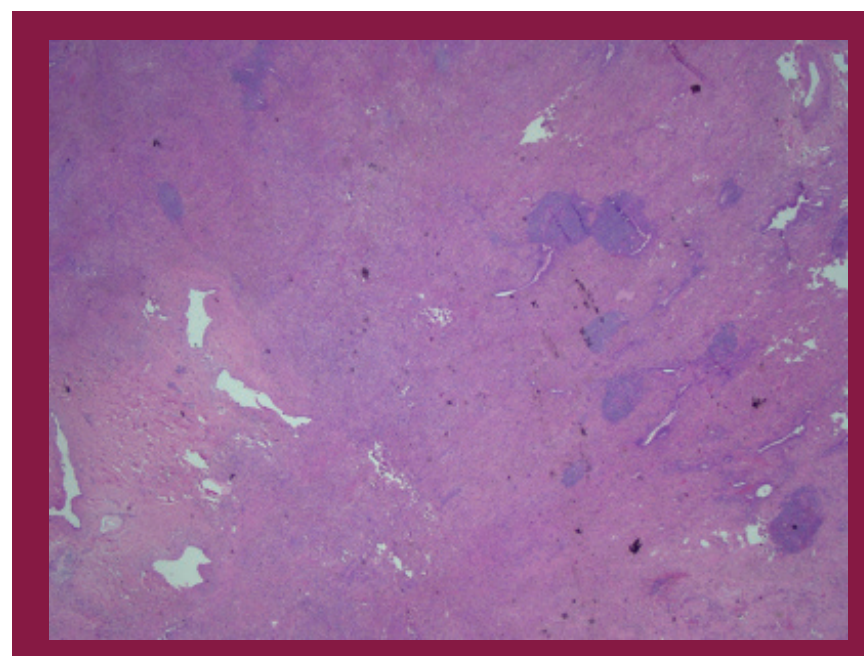

Figure 1d. Unclassified fibrosis with patternless distribution

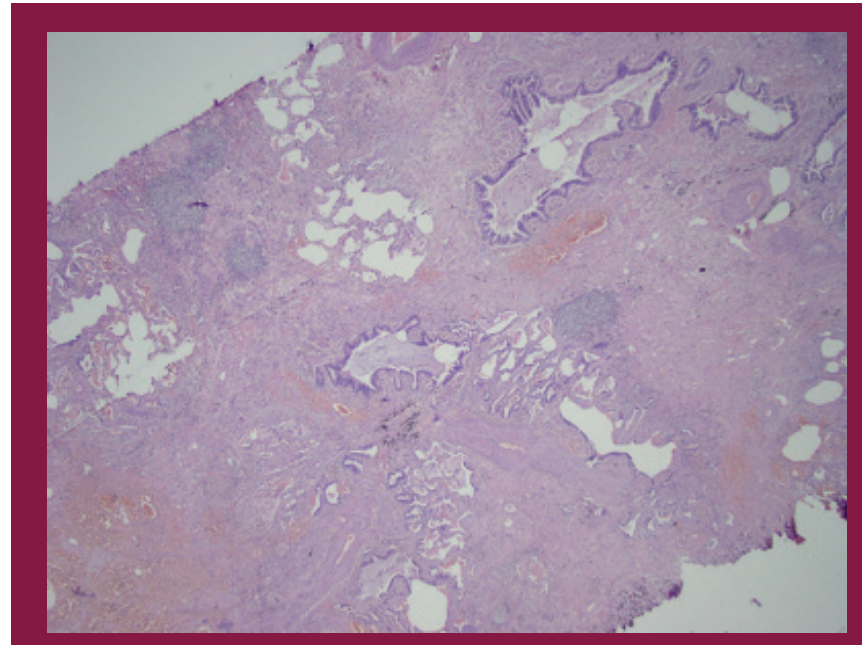

Figure 2. Intralobular fibrous obliteration with microcysts

chi-square, Student's t, Mann-Whitney U, and Fisher's Exact tests. Correlation analysis was performed using Spearman's correlation, Pearson's chi-squared test, linear model ANOVA, and bimodal logistic regression tests. Probability rate (p) less than 0.05 was accepted as statistically significant.

\section{Results}

A total of 226 cases with FIP were identified. The cases' demographic and clinical characteristics are shown in Table 1.

The characteristics of 17 cases whose predominant pattern was unclassified fibrosis are shown in Table 2.

Among all fibrotic cases, pneumoconiosis was detected in 5 cases (2.2\%). Silicosis was detected in 3 cases, and 1 case each had talcosis and coal pneumoconiosis. CF was the predominant pattern in coal pneumoconiosis, while unclassified fibrosis pattern was predominant in the other pneumoconioses. 


\begin{tabular}{|c|c|}
\hline Characteristics & Overall $(n=226)$ \\
\hline \multicolumn{2}{|l|}{ Gender } \\
\hline Female & 95 (42.0\%) \\
\hline Male & 131 (58.0\%) \\
\hline \multicolumn{2}{|l|}{ Age (years) } \\
\hline Mean (SD) & $57.8(11.2)$ \\
\hline Range & $25.0-80.0$ \\
\hline \multicolumn{2}{|c|}{ Predominant pattern } \\
\hline Unclassified & 17 (7.5\%) \\
\hline NSIP & 44 (19.5\%) \\
\hline CF & 80 (35.4\%) \\
\hline UIP & 11 (4.9\%) \\
\hline IFOM & 74 (32.7\%) \\
\hline \multicolumn{2}{|c|}{ Secondary pattern } \\
\hline None & 37 (7.5\%) \\
\hline DP & $2(1.1 \%)$ \\
\hline NSIP & 38 (20.1\%) \\
\hline $\mathrm{OP}$ & $11(5.8 \%)$ \\
\hline CF & 55 (29.1\%) \\
\hline SRIF & $1(0.5 \%)$ \\
\hline UIP & 41 (21.7\%) \\
\hline IFOM & 41 (21.7\%) \\
\hline \multicolumn{2}{|c|}{ Fibroblastic focus } \\
\hline Rare & 96 (42.5\%) \\
\hline Extensive & 23 (10.2\%) \\
\hline None & $107(47.3 \%)$ \\
\hline \multicolumn{2}{|l|}{ Bronchiectasis } \\
\hline Yes & $146(64.6 \%)$ \\
\hline No & $80(35.4 \%)$ \\
\hline \multicolumn{2}{|l|}{ Honeycombing } \\
\hline Yes & 140 (61.9\%) \\
\hline No & 86 (38.1\%) \\
\hline \multicolumn{2}{|l|}{ Ossification } \\
\hline Yes & 45 (19.9\%) \\
\hline No & 181 (80.1\%) \\
\hline \multicolumn{2}{|l|}{ Emphysema } \\
\hline No & $134(59.3 \%)$ \\
\hline Yes & 92 (40.7\%) \\
\hline \multicolumn{2}{|l|}{ UIP } \\
\hline Alternative & 159 (70.4\%) \\
\hline Indeterminate & 43 (19.0\%) \\
\hline Probable & $8(3.5 \%)$ \\
\hline Definite & $16(7.1 \%)$ \\
\hline \multicolumn{2}{|c|}{$\begin{array}{l}\text { NSIP: Non-specific interstitial pneumonia, CF: Centrilobular fibrosis, UIP } \\
\text { Usual interstitial pneumonia, IFOM: Intralobular fibrous obliteration with } \\
\text { microcysts, DP: Desquamative pneumonia, OP: Organizing pneumonia, SRIF } \\
\text { Smoking-related interstitial pneumonia, SD: Standard deviation }\end{array}$} \\
\hline
\end{tabular}

\begin{tabular}{l|l|}
$\begin{array}{l}\text { Table 2. Distribution of fibrosis cases with unclassified } \\
\text { predominant pattern }\end{array}$ \\
Unclassified & 17 \\
Non-diagnostic fibrosis & 9 \\
Silicosis & 3 \\
PPFE & 2 \\
Sarcoidosis & 1 \\
Talcosis & 1 \\
Chronic eosinophilic pneumonia & 1 \\
\hline PPFE: Pleuroparenchymal fibroelastosis
\end{tabular}

In terms of minor changes, 8 cases had loose granuloma and 5 had centrilobular isolated giant cells. Loose granuloma was the predominant pattern in $5.4 \%$ of IFOM and $5 \%$ of CF while isolated giant cells were detected in $4 \%$ and $2.5 \%$, respectively. Both lesions were present in $9.4 \%$ of IFOM and $7.5 \%$ of CF.

Pleuritis and SRIF were detected in 1 case each. Intense inflammation was observed in 7 cases and prominent lymphoid nodular hyperplasia in 1 case. One case with eosinophilia was in the NSIP group and the other was in the unclassified group.

The most common pathology pattern in the UIP groups was alternative (70.4\%) diagnosis and the least common was probable UIP (3.5\%). Histopathologic characteristics were compared between the UIP and non-UIP diagnostic groups of the study population (Table 3).

In the comparison of UIP and non-UIP diagnoses, there was no difference according to sex. Although the mean age was not discriminatory, the UIP group was slightly older than the nonUIP group. In cases with definite and probable UIP diagnoses, the most common pattern was UIP, while IFOM and unclassified fibrosis were less common. Predominant UIP pattern showed a significant difference in the exclusion of non-UIP diagnoses. The UIP pattern was found to have diagnostic sensitivity and specificity of $75 \%$ and $95 \%$, respectively.

IFOM was observed in $59.3 \%$ of all cases. It was associated with both predominant and secondary patterns (Figure 3). The prevalence of IFOM was significantly higher among cases with UIP diagnoses and was $26.2 \%$ in non-UIP. Its presence and absence were significant in the pathologic differential diagnosis. IFOM had a sensitivity of $87.5 \%$ and specificity of $73.7 \%$ in the diagnosis of UIP.

FF was observed in $83.3 \%$ of cases diagnosed with UIP. When compared to the non-UIP group, the difference was significant. The sensitivity and specificity of FF in UIP were $83 \%$ and $50 \%$, respectively.

Honeycombing and bronchiectasis were significantly more prevalent in the UIP diagnosis group. The sensitivity and specificity of bronchiectasis for a UIP diagnosis were $95 \%$ and $39 \%$, respectively. Ossification was detected in $19.9 \%$ of all cases and emphysema in $40 \%$. Neither made a significant difference for UIP. 
Table 3. Distribution of histopathologic lesion diagnoses

\begin{tabular}{|c|c|c|c|c|}
\hline Characteristics & UIP $(n=24)$ & Non-UIP $(n=202)$ & Total $(n=226)$ & $p$ \\
\hline Gender & - & - & - & 0.177 \\
\hline Female & 7 (29.2\%) & 88 (43.6\%) & 95 (42.0\%) & - \\
\hline Male & $17(70.8 \%)$ & $114(56.4 \%)$ & 131 (58.0\%) & - \\
\hline Age & - & - & - & 0.026 \\
\hline Mean (SD) & $62.6(7.9)$ & $57.3(11.4)$ & $57.8(11.2)$ & - \\
\hline Range & $45.0-76.0$ & $25.0-80.0$ & $25.0-80.0$ & - \\
\hline Predominant pattern & - & - & - & $<0.001$ \\
\hline UIP & 18 (75.0\%) & $9(4.5 \%)$ & 27 (11.9\%) & - \\
\hline NSIP & $0(0.0 \%)$ & 56 (27.7\%) & $56(24.8 \%)$ & - \\
\hline $\mathrm{CF}$ & $0(0.0 \%)$ & 119 (58.9\%) & 119 (52.7\%) & - \\
\hline Unclassified & $6(25.0 \%)$ & 18 (8.9\%) & 24 (10.6\%) & - \\
\hline IFOM & - & - & - & $<0.001$ \\
\hline No & $3(12.5 \%)$ & 149 (73.8\%) & 152 (67.3\%) & - \\
\hline Yes & $21(87.5 \%)$ & $53(26.2 \%)$ & 74 (32.7\%) & - \\
\hline FF & - & - & - & 0.001 \\
\hline No & $4(16.7 \%)$ & $103(51.0 \%)$ & 107 (47.3\%) & - \\
\hline Yes & $20(83.3 \%)$ & 99 (49.0\%) & 119 (52.7\%) & - \\
\hline Bronchiectasis & - & - & - & $<0.001$ \\
\hline No & $1(4.2 \%)$ & 79 (39.1\%) & 80 (35.4\%) & - \\
\hline Yes & 23 (95.8\%) & $123(60.9 \%)$ & $146(64.6 \%)$ & - \\
\hline Honeycombing & - & - & - & $<0.001$ \\
\hline No & $0(0.0 \%)$ & 86 (42.6\%) & 86 (38.1\%) & - \\
\hline Yes & 24 (100.0\%) & 116 (57.4\%) & 140 (61.9\%) & - \\
\hline Ossification & - & - & - & 0.231 \\
\hline No & 17 (70.8\%) & 164 (81.2\%) & 181 (80.1\%) & - \\
\hline Yes & 7 (29.2\%) & 38 (18.8\%) & 45 (19.9\%) & - \\
\hline Emphysema & - & - & - & 0.064 \\
\hline No & $10(41.7 \%)$ & 124 (61.4\%) & 134 (59.3\%) & - \\
\hline Yes & $14(58.3 \%)$ & 78 (38.6\%) & 92 (40.7\%) & - \\
\hline
\end{tabular}

Excluded cases included 16 with Langerhans cell histiocytosis X, 4 with lymphangioleiomyomatosis, 1 with BHD syndrome, and 5 with concomitant carcinoma and FIP.

\section{Discussion}

Our study has demonstrated which histologic lesions have greater validity in the pathologic diagnosis of FIP. Guidelines define UIP as combination of the fibrotic pattern, FF, and honeycomb cysts $(1,2)$. Our study emphasizes that these lesions have an important place in diagnosis. On the other hand, while less common, it is a fact that the non-UIP group can also include these lesions. The characteristic interstitial fibrotic pattern model is undoubtedly important in decision-making $(6,7)$. However, the presence of lesions in the histologic examination may not be enough to narrow down to a single diagnosis.

FIP is a group of dynamic and progressive diseases. The non-stop manner of fibrosis can destroy its characteristic patterns. IFOM, first described by Kradin (5), may be the endpoint of fibrosis. We determined that this lesion might be an important indicator in the diagnosis of UIP. The presence of IFOM as predominant or secondary pattern will obviously facilitate the pathology diagnosis of UIP. Bridging fibrosis in the center of the lobule extending to the septum or pleura causes a structural deformity similar to IFOM (4,8). This indicates that fibrosis may be more complex than expected in pattern determination (9). As a result, IFOM may be important both in the diagnosis of UIP and the demonstration of progressive fibrosis.

The provisional diagnosis of UIP most frequently encountered by the lung pathologist is often in reality an alternative diagnosis in daily practice. In the present study, $89.4 \%$ of our cases had a possible UIP or alternative diagnosis. Moreover, the fact that CF was most common in these cases is striking. In the literature, it has been emphasized that chronic hypersensitivity pneumonia is the most important disease in the differential diagnosis for UIP (10). It is suggested that a substantial proportion of cases were misdiagnosed as UIP in the past (11). For this reason, 


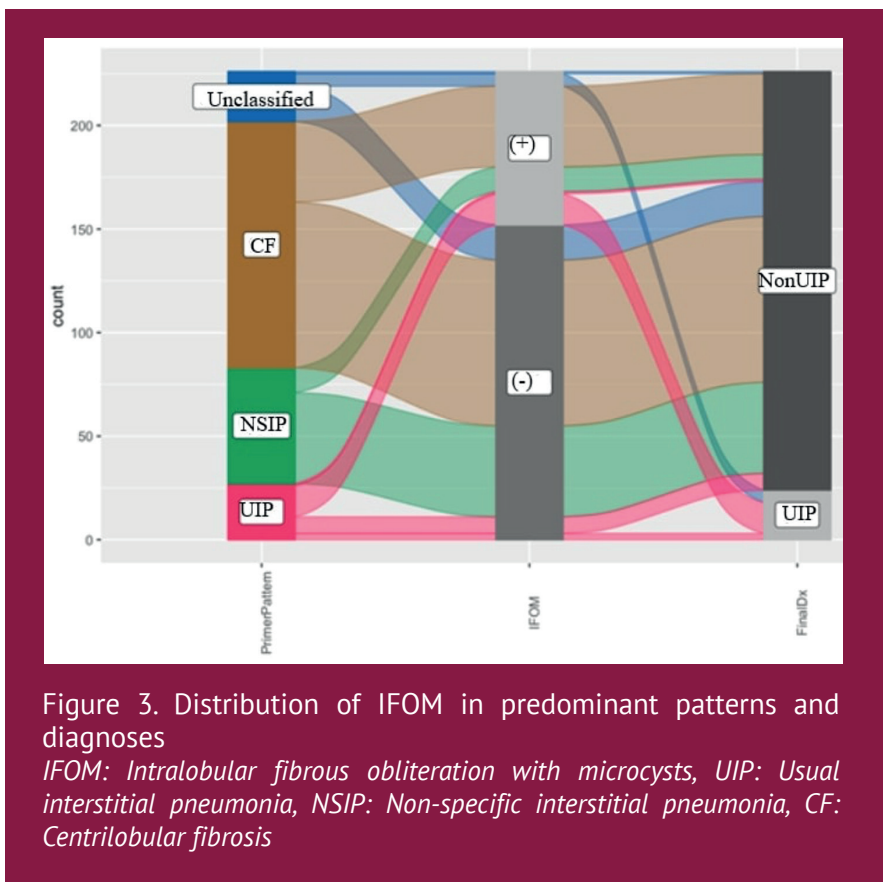

quantitative analysis or scoring of the lesions is recommended $(11,12)$. Despite all of these efforts, however, the coexistence of UIP and CF patterns in the same tissue is possible. The same difficulty arises when diagnosing NSIP (13). In the guidelines, honeycomb cysts are among the main diagnostic criteria for UIP. Although our study supports this approach, others have reported that chronic hypersensitivity can lead honeycomb cysts (8). Therefore, a CF-focused diagnostic approach may be more accurate in FIP pathologic evaluation. In addition, the differential diagnosis should include rare diseases such as pneumoconiosis and pleuroparenchymal fibroelastosis.

The combination of FIP and emphysema is not uncommon (14). Emphysema is usually accompanied by UIP and they often occur together in the lower lobe (15). Although there was no significant difference in our study in terms of the coexistence of emphysema and UIP, the fact that emphysema was present in $40.7 \%$ of all cases is quite important. Similarly, although it is a component of obstructive pulmonary disease, bronchiectasis develops when interstitial fibrosis destroys the alveolar structure and destroys the architectural framework. In particular, the presence of traction bronchiectasis, an important radiologic criterion, may be as valuable as FF and honeycomb fibrocysts in pathologic evaluation.

\section{Study Limitations}

There are some limitations of this study. First, the clinical and radiologic findings of the cases were excluded from the scope of the study. A connection could not be made between the lesions and etiology due to the lack of clinicoradiologic diagnosis. Another limitation is that only surgical biopsy cases were included in the study. Cases diagnosed with conventional transbronchial biopsy and cryobiopsy were not included due to the difficulty in detecting multiple patterns.

\section{Conclusion}

The pathological evaluation of FIP patterns involves specific challenges. Although not a typical pattern, it is interesting that IFOM, which completely obliterates the lobular anatomy, was second most common after CF among the predominant patterns observed in our study. This indicates that when identifying lesions, coexistent patterns must be reported rather than a diagnosis. CF-focused diagnostic approach may be more accurate in FIP pathologic evaluation.

\section{Acknowledgments}

The authors thank Serdar Balcı MD for statistical analysis.

\section{Ethics}

Ethics Committee Approval: Study design was approved by Local Ethical Committee (University of Health Sciences Turkey, İstanbul Training and Research Hospital). The study protocol number and date are 2259/20 (08/05/2020). And also, it was approved by Hospital Science Committee (protocol number is 244-5/20).

Informed Consent: Informed consents were obtained from all study patients.

Peer-review: Externally peer-reviewed.

\section{Authorship Contributions}

Surgical and Medical Practices: H.N.Ü., N.F., N.Ü., E.Ç., Concept: H.N.Ü., Design: H.N.Ü., Data Collection or Processing: H.N.Ü., N.F., N.Ü., Analaysis or Interpretation: H.N.Ü., E.Ç., Literature Search: H.N.Ü., Writing: H.N.Ü.

Conflict of Interest: No conflict of interest was declared by the authors.

Financial Disclosure: The authors declared that this study received no financial support.

\section{References}

1. Raghu G, Remy-Jardin M, Myers JL, Richeldi L, Ryerson CJ, Lederer DJ, et al. Diagnosis of idiopathic pulmonary fibrosis An Official ATS/ERS/JRS/ALAT Clinical practice guideline. Am J Respir Crit Care Med. 2018;198:e44-e68. [Crossref]

2. Lynch DA, Sverzellati N, Travis WD, Brown KK, Colby TV, Galvin JR, et al. Diagnostic criteria for idiopathic pulmonary fibrosis: a Fleischner Society White Paper. Lancet Respir Med. 2018;6:138-153. [Crossref]

3. Larsen BT, Colby TV. Update for pathologists on idiopathic interstitial pneumonias. Arch Pathol Lab Med. 2012;136:1234-1241. [Crossref]

4. Smith ML. Update on pulmonary fibrosis: Not all fibrosis is created equally. Arch Pathol Lab Med. 2016;140:221-229. [Crossref] 
5. Kradin RL. Honeycomb lung: Time for a change. Arch Pathol Lab Med. 2015;139:1398-1399. [Crossref]

6. Hashisako M, Fukuoka J. Pathology of idiopathic interstitial pneumonias. Clin Med Insights Circ Respir Pulm Med. 2016;9(Suppl 1):123-133. [Crossref]

7. Kadoch MA, Cham MD, Beasley MB, Ward TJ, Jacobi AH, Eber CD, et al. Idiopathic Interstitial Pneumonias: A Radiology-Pathology Correlation Based on the Revised 2013 American Thoracic Society-European Respiratory Society Classification System. Curr Probl Diagn Radiol. 2015;44:15-25. [Crossref]

8. Takemura T, Akashi T, Kamiya H, Ikushima S, Ando T, Oritsu M, et al. Pathological differentiation of chronic hypersensitivity pneumonitis from idiopathic pulmonary fibrosis/usual interstitial pneumonia. Histopathology. 2012;61:1026-1035. [Crossref]

9. Kambouchner M, Levy P, Nicholson AG, Schubel K, Magois E, Feuillet S, et al. Prognostic relevance of histological variants in nonspecific interstitial pneumonia. Histopathology. 2014;65:549-560. [Crossref]

10. Churg A, Bilawich AM, Wright JL. Pathology of chronic hypersensitivity pneumonitis: What is it? What are the diagnostic criteria? Why do we care? Arch Pathol Lab Med. 2018;142:109-119. [Crossref]
11. Churg A. Centrilobular Fibrosis in Fibrotic (Chronic) Hypersensitivity Pneumonitis, Usual Interstitial Pneumonia, and Connective Tissue Disease-Associated Interstitial Lung Disease. Arch Pathol Lab Med. 2020;144:1509-1516. [Crossref]

12. Tanizawa K, Ley B, Vittinghoff E, Elicker BM, Henry TS, Wolters PJ, et al. Significance of bronchiolocentric fibrosis in patients with histopathological usual interstitial pneumonia. Histopathology. 2019;74:1088-1097. [Crossref]

13. Tomassetti S, Ryu JH, Piciucchi S, Chilosi M, Poletti V. Nonspecific Interstitial Pneumonia: What Is the Optimal Approach to Management? Semin Respir Crit Care Med. 2016;37:378-394. [Crossref]

14. Berg K, Wright JL. The pathology of chronic obstructive pulmonary disease: Progress in the 20th and 21st centuries. Arch Pathol Lab Med. 2016;140:1423-1428. [Crossref]

15. Kinoshita Y, Watanabe K, Ishii H, Kushima H, Fujita M, Nabeshima K. Distribution of emphysema and fibrosis in idiopathic pulmonary fibrosis with coexisting emphysema. Histopathology. 2019;74:1103-1108. [Crossref] 